\title{
MIGRATION OF HIGHLY QUALIFIED WORKERS FROM UKRAINE: REASONS AND WAYS TO OVERCOME ${ }^{1}$
}

\section{Petrushenko Y.M.}

Doctor of Economics, professor

The Department of International Economic Relations, Sumy State University, y.petrushenko@uabs.sumdu.edu.ua

\section{Zemlyak N.V.,}

PhD-student,

The Department of International Economic Relations, Sumy State University, n.zemliak@uabs.sumdu.edu.ua

\section{Shapoval V.Y.,}

student

The Department of International Economic Relations, Sumy State University, vladyslav.y.shapoval@gmail.com

\section{Dibrova V.V.}

entrepreneur

vladyslav.dibrova@gmail.com

\begin{abstract}
The migration of highly skilled workers is becoming an increasingly important factor that is influencing the development of specific countries as well as different regions of the world. In fact, in the European Union, the tendency of low-skilled workers shortage is changing to the trend of promoting the highly skilled workers migration, which can create added value and contribute to pension funds for the aging population in those states. At the same time, due to the loss of highly qualified personnel, the recipient countries are losing the pace of their economic development. The relevance of this study is also enhanced by changing conditions for international labor migration to the European Union in connection with the COVID-19 pandemic, including for highly qualified Ukrainian professionals.

The article examines the reasons of highly skilled workers migration processes, analyzes the consequences for different stakeholders and provides methods to reduce the scale of such migration. To analyze the reasons of highly qualified specialists labor migration, the model of "Push and Pull" factors was used on the example of Ukraine and the European Union. The positive and negative consequences of the highly qualified specialists' migration growth for various stakeholders of this process have been identified.

It is also proved that despite the fact that salaries are growing in real terms in Ukraine, the difference in salaries in the main areas of emigration to the EU is so large that it is likely to continue to motivate people to work and earn abroad. Moreover, the existence of a large and growing Ukrainian diaspora tends to encourage the migration of other family members and friends, providing informational and logistical support in destination countries. This attraction may increase in the coming years, and the diaspora will continue to expand.

In the article, it is also described the impact of the COVID-19 pandemic on the highly qualified professionals migration, and it gives a number of proposals or recommendations that could be implemented at the level of state migration policy to address highly qualified professionals labor migration or at least improve the current situation The proposed recommendations of the migration policy to confront the negative effects of the COVID-19 pandemic include the establishment of a mechanism for coordination and consultation between all government institutions authorities and agencies involved in labor migration, as well as the establishment of tripartite procedures for advising employers and workers of migration organizations and considering their opinions on the given topic.

Keywords: migration, highly qualified specialists, "Push and Pull" factors model, economic growth, state policy.
\end{abstract}

DOI: $10.21272 / 1817-9215.2021 .2-8$

\section{INTRODUCTION}

In today's globalized world, the migration of highly skilled workers has become significant. Labor flows of different qualifications and specialties are constantly moving between countries, which significantly affects the demographic situation of donor-countries, their economies and labor markets. This problem mainly concerns states with unstable

\footnotetext{
${ }^{1}$ The article was published as part of a research projects "Convergence of economic and educational transformations in the digital society: modeling the impact on regional and national security"(No. 0121U109553) and "Reforming the lifelong learning system in Ukraine for the prevention of the labor emigration: a coopetition model of institutional partnership" (No. 0120U102001).
} 
economies, which are not able to fully meet the needs of their population. Consequently, there is a desire to move to another country where intelligent work is valued, where higher salaries, better employment conditions, opportunities for self-realization and trainings are. This is beneficial for the host countries, as they have the opportunity to choose more highly qualified workers. That donor or sending countries are losing their intellectuals. Therefore, the study of migration processes of highly qualified workers is relevant and important.

\section{ANALYSIS OF RECENT SOURCES AND PUBLICATIONS}

Many domestic scientists, for instance, Baranyk Z. [1], Libanova E. and Poznyak V. [2, 3], Malinovska A. [4], Nikolaevsky V. [5], Grudzinsky O. [6], Maidanik I. [7], Petrova J. [8] Semikina M. [9] and many others paid attention to the issue of highly qualified workers migration processes from Ukraine.

Baranyk Z., for example, in her works considered the reasons, consequences and problems of intellectual migration and the effectiveness of migration policy by the state [1]. O. Grudzinsky studied the causes, advantages, and disadvantages of international scientific and technological cooperation in the framework of international migration [6]. In Petrova's research, intellectual migration is considered from the standpoint of highly qualified scientific personnel [8]. Even though this topic is considered in the works of many scientists, the problem of migration of highly skilled workers requires further detailed research.

The purpose of the article is to study the highly skilled workers migration processes, identify the reasons and find ways to reduce migration.

\section{RESEARCH RESULTS}

Labor emigration has been a common phenomenon in Ukraine since the country's independence - 1991. According to a survey conducted by the State Statistics Service of Ukraine (SSSU) in 2017, the number of migrant workers was 1.3 million. Previous surveys conducted by the State Statistics Service in 2007 and 2012 estimated the number of migrants at 1.48 million and 1.18 million, respectively. Researchers dealing with Ukrainian migration believe that the SSSU survey underestimates the total number of migrants, but this is the most detailed survey of Ukrainian emigration, therefore, helps to highlight its main features, structure, and directions of migrants [12, 13].

SSSU surveys show that the main destination countries for Ukrainian labor migrants have changed since the 2014-military-conflict. According to their previous survey conducted in 2012, Russia was the most popular destination, having $43 \%$ of Ukrainians working there. In 2017, Poland became the most popular destination for Ukrainian labor migrants $(39 \%)$. The rapid increase in the number of migrants to Poland can be explained by the dynamic growth of the Polish economy and the large number of vacancies, as well as visa liberalization (since 2017) and legislative changes that promote the employment of Ukrainians. Despite tense twoparties' relations between Ukraine and Russia, the latter country still attracted $26 \%$ of Ukrainian labor migrants in 2017. Italy and the Czech Republic are considered as the third and fourth most popular destinations; $67 \%$ of Ukrainian migrant workers worked in EU member states in 2017 against 54\% in 2012. The right of Ukrainians to work depends on the national rules of the host countries, also within the European Union, which partly explains the choice of destination countries by migrants.

With the help of the analysis of remittances from abroad, it is possible to determine the main directions of labor migration from Ukraine (Fig. 1).

The main countries of the European Union for workers are Poland, the Czech Republic and Germany.

According to a study by the European Commission, the share of migrants with higher education is $33 \%$ [11], but for a number of reasons, such as political, economic, social, highly skilled workers are forced to work abroad.

In the 1960s, Robert Edward Lee proposed the migration theory "Push and Pull factors". According to this model, there are different groups of migration factors in each territory: 
those that hold, attract, push, determine arrivals and departures, and some factors affect most people, and some only some individuals.

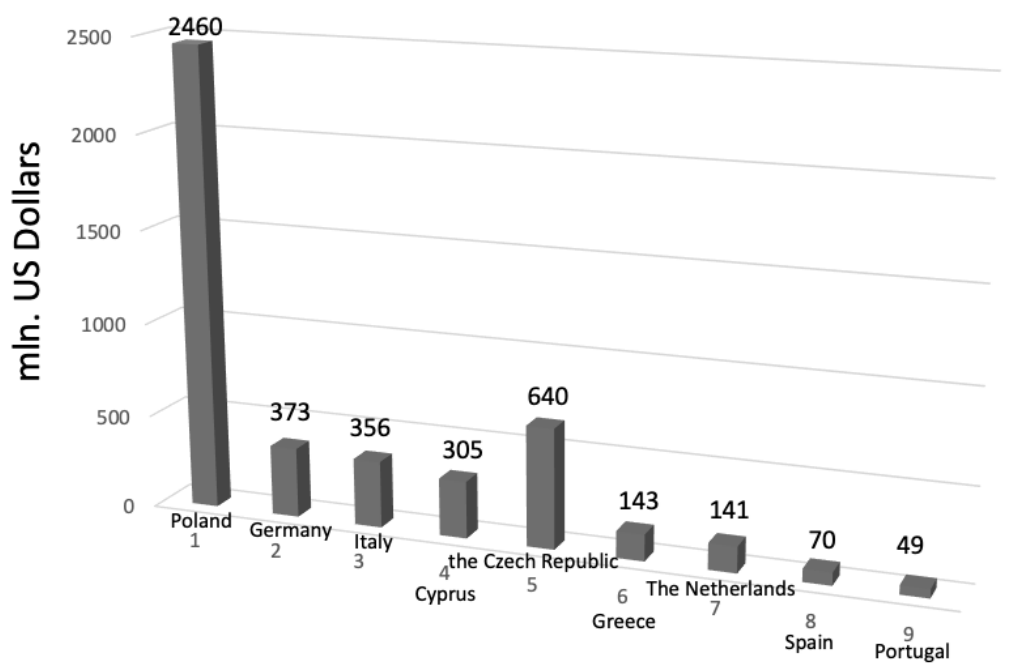

Figure 1 -Remittances to Ukraine from the most important countries of the European Union in 2020 (million USD) [10]

It is proposed to consider the influence of factors that push out from the country (Push) and those that attract to another (Pull) on the example of Ukraine and the European Union (Table 1).

Table 1 - Push and Pull factors in the field of labor migration between Ukraine and the EU

\begin{tabular}{|c|c|c|}
\hline Type of factors & Push-factors from Ukraine & Pull factors to the European Union \\
\hline Political & $\begin{array}{l}\text { - bureaucracy; } \\
\text { - administrative restrictions on conducting business; } \\
\text { - the presence of a military conflict. }\end{array}$ & $\begin{array}{l}\text { - lower level of corruption; } \\
\text { - political stability. }\end{array}$ \\
\hline Economical & $\begin{array}{l}\text { - low salaries; } \\
\text { - high cost of living; } \\
\text { - economic instability; } \\
\text { - high taxes; } \\
\text { - high unemployment. }\end{array}$ & $\begin{array}{l}\text { - higher salaries; } \\
\text { - low cost of living; } \\
\text { - stable economic development. }\end{array}$ \\
\hline Working & $\begin{array}{l}\text { - poor working conditions; } \\
\text { - low level of protection and security from the labor } \\
\text { protection representatives; }\end{array}$ & $\begin{array}{l}\text { - high level of labor protection; } \\
\text { - the best working conditions; } \\
\text { - career growth. }\end{array}$ \\
\hline Social & $\begin{array}{l}\text { - low level of social protection; } \\
\text { - low level of medical services. }\end{array}$ & $\begin{array}{l}\text { - compulsory medical insurance and } \\
\text { high level of medical services; } \\
\text { - stable benefits. }\end{array}$ \\
\hline
\end{tabular}

Migration is a selective process, and the same factors affect various people differently. Attractive factors play an important role for highly qualified professionals, because migration usually means increasing income levels, moving up in the career ladder and getting better offers in the professional field. For low-skilled workers, on the other hand, negative, repulsive factors are more important.

Thus, it is seen that there is a high number of repulsive factors for highly qualified workers in Ukraine. These include insufficient jobs, low wages, military conflict, low health care and social protection.

The increase in migration has both positive and negative consequences for various stakeholders in this process (Table 2).

Given the consequences of labor emigration from Ukraine described above, the question of how Ukraine could adjust its policies to improve benefits and limit the costs associated with its large outflow of workers is relevant. 
Studies of labor migration emphasize, first, the benefits of interacting with the diaspora and encouraging migrants, especially highly qualified personnel, to invest and return to their homeland [14].

Table 2 - Positive and negative consequences of labor migration for Ukraine and host countries of migrants

\begin{tabular}{|c|c|c|}
\hline & $\begin{array}{l}\text { For Ukraine } \\
\end{array}$ & For host countries \\
\hline \multirow{4}{*}{ Positive } & Increase in remittances from migrant workers & Satisfying open vacancies \\
\hline & $\begin{array}{l}\text { Reducing unemployment in the domestic } \\
\text { market }\end{array}$ & $\begin{array}{l}\text { Decrease in the average market value of } \\
\text { salaries }\end{array}$ \\
\hline & \multirow{2}{*}{$\begin{array}{l}\text { Return of some employees with new } \\
\text { experience and knowledge }\end{array}$} & Stimulating consumer demand \\
\hline & & Boosts economic development \\
\hline \multirow{5}{*}{ Negative } & $\begin{array}{l}\text { Changing the balance of highly qualified and } \\
\text { low-skilled professionals }\end{array}$ & $\begin{array}{l}\text { Local labor begins to look for work in } \\
\text { another country, there are market } \\
\text { asymmetries }\end{array}$ \\
\hline & $\begin{array}{l}\text { Increasing the value of the domestic labor } \\
\text { market }\end{array}$ & $\begin{array}{l}\text { Increasing competition with the local } \\
\text { population }\end{array}$ \\
\hline & Declining production rates in the country & \multirow[t]{3}{*}{ Risk of illegal migration is increased } \\
\hline & Import of labor resources from abroad & \\
\hline & $\begin{array}{l}\text { Additional state expenditures for training new } \\
\text { specialists }\end{array}$ & \\
\hline
\end{tabular}

Benefits include the return of skills, the dissemination of technological and managerial knowledge, and the emergence of modern small and medium-sized enterprises. Returnees can also bring significant savings: according to an IOM survey (2016) [15], the amount of savings accumulated by Ukrainian migrants abroad is more than twice the number of remittances sent. Some countries have managed to attract returning emigrants (for example, Ireland) and to involve the diaspora in the development of high-tech industries (India, Israel). Such programs are addressed in most cases to highly skilled migrants. For example, the Moldovan program PARE 1+1, with the support of the EU, provided subsidies for the creation of new small and medium enterprises by emigrants returning to Moldova. In December 2019, the Ukrainian government announced a low-interest loan program "Come and Stay", aimed at supporting the creation of small new companies, especially to encourage citizens working abroad to return home and start a business.

In addition to special programs for returnees, it is necessary to create a more attractive business environment that would be useful both to encourage migrants to return and to stimulate investment in the economy. In Ukraine, this requires more efficient public institutions, intensified efforts to fight corruption, implement reforms in areas such as the land market or the judiciary, and improve infrastructure. Increasing satisfaction with local facilities such as health care, education, housing, the environment, roads, and transportation may also improve the likelihood that people will want to return from exile or stay in the country [16].

\section{CONCLUSIONS}

Emigration from 2.2 to 2.7 million people (according to various estimates) has helped reduce labor supply in Ukraine and labor shortages in certain occupations. Despite the fact that salaries in Ukraine are growing in real terms, the difference in salaries, in the main areas of emigration to the EU, is so large that it is likely to continue to motivate people to work and earn abroad. Moreover, the existence of a large and growing Ukrainian diaspora tends to encourage the migration of other family members and friends, providing informational and logistical support in those countries. This attraction may increase in the coming years, and the diaspora may continue to expand. At the same time, destination countries for some emigrants may change, especially due to the gradual opening of the German labor market for Ukrainian workers. However, linguistic, and geographical similarity will continue to weigh in favor of countries such as Poland and the Czech Republic. Regarding the migration of Ukrainians to the European Union, in all respects, it can be stated that the European Union is 
experiencing one of the most difficult moments, related, in particular, to problems such as migration. This is a turning point, which is also due to such pressing issues as Brexit or expulsion from citizenship under the European project. Given all this and bearing in mind that migration in the world, in general and in Europe specifically, is a present and future reality, a reconfiguration of environmental policy is at least necessary.

The following are several suggestions or recommendations that could be considered to address migration issues or at least improve the current situation (these recommendations also apply to migration issues of highly qualified professionals):

- formulate and implement national, regional and multilateral labor migration policies, guided by international labor standards, other relevant international standards and multilateral agreements concerning migrant workers;

- ensure continuity between labor migration, employment and other national policies in order to understand the broad social and economic impact of labor migration, as well as to promote decent work for all and to promote full, productive and free choice of employment;

- create a mechanism to ensure coordination and consultation between all government instututions, authorities and agencies involved in labor migration;

- implement policies to address specific vulnerabilities of certain groups of migrant workers, including migrant workers in abnormal conditions;

- ensure that labor migration policies take into account gender aspects and emphasize the challenges that women often face in the migration process;

- ensure that the specific structures and mechanisms in these government institutions have the necessary functions and capabilities to develop, formulate and implement labor migration policies, including, if possible, the establishment of a dedicated unit to work with migrant workers;

- Establish tripartite procedures to ensure that employers 'and workers' organizations are consulted on labor migration and that their views are considered.

All these recommendations and suggestions could take place in society, as they are not unattainable or unrealized actions. However, brakes or barriers are often set by those who could change the situation for the better.

The 2020 pandemic and its aftermath have changed the lives of people around the world. And it has had a particularly strong impact on the lives of migrants, according to a report by the Organization for Economic Co-operation and Development (OECD). During the fight against coronavirus and anti-epidemiological restrictions, migrants played a significant role in health, retail, and supply.

The pandemic has sharply reduced migration to OECD countries. According to preliminary data, in the first half of 2020 the influx of migrants was twice less than in the same period last year. The issuance of new visas and permits in OECD countries in the first half of 2020 fell by $46 \%$ compared to the same period in 2019. This is the largest reduction ever recorded. In the second quarter, the decline was $72 \%$ (Figure 2).

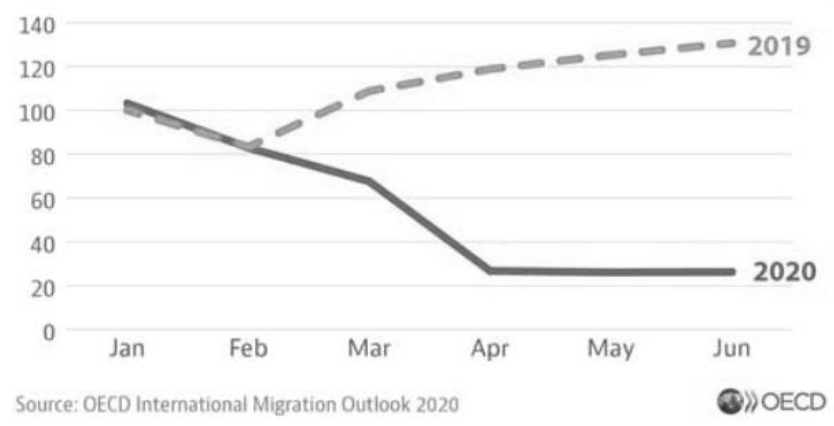

Figure 2 - Permits and visas issued to OECD countries in 2019 and 2020 [17] 
In general, thanks to the COVID-19 pandemic, it was a historic low point for international migration in the OECD region in 2020. And, according to forecasts, soon the situation is unlikely to change, even if the economy recovers. As one of the reasons, experts call the transformation of the labor market caused by the pandemic and the growing transition to online work. At the same time, despite the fact that highly qualified specialists are in their countries, there is a kind of remote labor migration, as they work for the economies of other countries.

\begin{abstract}
АНОТАЦІЯ
Петрушенко Ю.М., Земляк Н.В., Шаповал В.Ю., Діброва В.В. Міграція висококваліфікованих працівників з України: причини та способи подолання

Міграція висококваліфікованих працівників стає все більи важливим фактором, що впливає на розвиток як окремих країн, так $і$ регіонів світу. Зокрема, в Європейському Союзі тенденція нестачі низькокваліфікованих працівників змінюється на тенденцію сприяння міграції висококваліфікованих працівників, які можуть створювати додану вартість і наповнювати пенсійні фонди для населення, що старіє. Водночас від втрати висококваліфікованих кадрів країни-реципієнти втрачають в темпах свого економічного розвитку. Актуальність даного дослідження посилюється також зміною умов для міжнародної трудової міграиії до країн Свропейського Союзу у зв'язку з пандемією СОVID-19, в тому числі для українських високваліфікованих фахівичв.

У статті досліджуються причини міграчійних процесів висококваліфікованих працівників, аналізуються наслідки для різних стейкхолдерів та методи зменшення масштабів такої міграції. Для аналізу спричин трудової міграчії високваліфікованих фахівців було використано модель «Push and Pull» факторів на прикладі Украӥни та краӥн Свропейського Союзу. Визначено позитивні так і негативні наслідки зростання масштабів міграції високваліфікованих фахівців для різних стейкхолдерів цього процесу.

Обгрунтовано, щчо не зважаючи на те, що заробітна плата в Україні зростає в реальному вираженні. різниця в зарплатах за основними напрямками еміграчії в СС настільки велика, щуо вона, ймовірно, продовжить мотивувати людей працювати та заробляти за кордоном. Більше того, існування великої та зростаючої української діаспори має тенденцію заохочувати міграцію інших членів родини та друзів, забезпечуючи інформачійну та матеріально-технічну підтримку в крайнах призначення. Цей фактор притягання може посилитися в найближчі роки, а діаспора буде продовжувати розиирюватися.

В статті також аналізується вплив пандемії COVID-19 на міграцію висококваліфікованих фахівців та визначено низку пропозичій чи рекомендацій, які можна було б запровадити на рівні міграчійної політики держави, щюб вирішити проблеми навколо трудової міграції високваліфікованих фахівців або принаймні покращитти поточну ситуацію. Запропоновані рекомендації міграційної політики протидії негативним наслідкам пандемії COVID-19 стосуються створення механізму забезпечення координації та консультачіи між усіма урядовими міністерствами, органами влади та відомствами, щзо беруть участь у трудовій міграиії, а також встановлення тристоронніх прочедур для забезпечення консультачій роботодавців та організацій працівників з питань трудової міграчї та врахування їх думок.
\end{abstract}

Ключові слова: міграція, високваліфіковані фахівці, модель «Риsh and Pull» факторів, економічне зростання, державна політика.

\title{
СПИСОК ЛІТЕРАТУРИ
}

1.Бараник 3.П. (2014). Інтелектуальна міграція як об'єкт статистичного дослідження. Ефективна економіка. 2014. №6. URL: http://www.economy.nayka.com.ua/?op=1\&z=3096 (дата звернення: 13.06.2021).

2. Позняк О., Федорович I. (2014). Дослідження з питань інтеграції, злочинів на грунті ненависті та дискримінації різних категорій мігрантів. Міжнародна організація з міграції. Представництво в Україні. 2014. $101 \mathrm{c}$.

3. Зовнішні трудові міграції населення України / За ред. Е.М. Лібанової, О.В. Позняка. К.: РВПС України ПАН України, 2002. 206 с.

4. Малиновська О.А. (2004) Мігранти, міграція та Українська держава: аналіз управління зовнішніми міграціями: моногр. К.: Внд-во НАДУ. 2004. 236 с.

5. Ніколаєвський В.М. (2006). Інтелектуальна міграція: причини, наслідки, виклики. Вісник ХНУ ім. В.Н. Каразіна. «Соціологічні дослідження сучасного суспільства: методологія, теорія, методи». 2006. № 723. С. $140-147$

6. Грудзинский А.О., Балабанова Е.С., Пекушкина О.А. (2004). Европейский трансфер технологий: кооперация без «утечки мозгов». Социологические исследования. 2004. № 11. С. 123-131.

7. Майданік I. (2009) Інтелектуальна міграція в Україні у контексті міжнародної наукової співпраці. Україна: аспекти праці. 2009. № 5. С. 34-38.

8. Міграція і толерантність в Україні / За ред. Я. Пилинського. К.: Стилос. 2007. № 6. 191 с.

9. Семикіна М. (2004). Людський капітал та інвестиційне регулювання його мобільності в конкурентних умовах. Вісник Тернопільської академії народного господарства. 2004. Вип. 5-1. С. 107-114.

10. Грошові перекази в Україну (2021). Міністерство фінансів України. URL: https://index.minfin.com.ua/ua/economy/transfer/ (дата звернення: 13.06.2021). 
11. European Commission/EACEA/Eurydice (2018). The European Higher Education Area in 2018: Bologna Process Implementation Report. URL: https://eacea.ec.europa.eu/nationalpolicies/eurydice/content/european-higher-education-area-2018-bologna-process-implementation-report_en (дата звернення: 17.0.6.2021).

12. State Statistics Service of Ukraine (SSSU 2017), Зовнішня Трудова Міграція Населення (за результатами модульного вибіркового обстеження), Kyiv. URL: http://ukrstat.gov.ua/druk/publicat/kat_u/publ11_u.htm(дата звернення: 15.06.2021).

13. Звіт щодо методології, організації проведення та результатів модульного вибіркового обстеження 3 питань трудової міграції в http://ukrstat.gov.ua/druk/publicat/kat_u/2013/dop/12_13/zvit.zip (дата звернення: 15.06.2021).

14. Kapur D., McHale J. (2012). Economic Effects of Emigration on Sending Countries, Oxford Handbook of the Politics of International Migration, pp. 131-147 (дата звернення: 17.06.2021).

15. International Organisation for Migration (IOM 2016), Migration as an Enabler of Development in Ukraine. A study on the nexus between development and migration-related financial flows to Ukraine. Kyiv, URL: http://www.iom.org.ua/sites/default/files/iom_migration_as_an_enabler_of_development_in_ukraine.pdf (дата звернення: 17.06.2021).

16. EBRD (2018), Work in Transition, Transition Report 2018-19. URL: https://www.ebrd.com/news/publications/transition-report/transition-report-201819.html (дата звернення: 15.06. 2021).

17. COVID-19 crisis puts migration and progress on integration at risk. (2021). URL: https://www.oecd.org/newsroom/covid-19-crisis-puts-migration-and-progress-on-integration-at-risk.htm (дата звернення: 13.06.2021).

\section{REFERENCES}

1. Baranik Z.P. (2014). Intellectual migration as an object of statistical research. Efficient economy. 2014. №6. URL: http://www.economy.nayka.com.ua/?op=1\&z=3096 (Accessed 13 Jun 2021).

2. Poznyak O., Fedorovich I. (2014). Research on integration, hate crimes and discrimination against different categories of migrants. International Organization for Migration. Representation in Ukraine. 2014. 101 p.

3. External labor migration of the population of Ukraine / Ed. E.M. Libanova, OV Pozniak. K .: RVPS Ukrainy PAN Ukrainy, 2002. 206 p.

4. Malinovskaya OA (2004) Migrants, migration and the Ukrainian state: analysis of external migration management: monograph. K .: Vnd-vo NADU. 2004. 236 p.

5. Nikolaevsky VM (2006). Intellectual migration: causes, consequences, challenges. Bulletin of KhNU named after V.N. Karazina. "Sociological research of modern society: methodology, theory, methods." 2006. № 723. S. $140-147$.

6. Grudzinsky AO, Balabanova ES, Pekushkina OA (2004). European technology transfer: cooperation without a "brain drain". Sociological research. 2004. № 11. S. 123-131.

7. Maidanik I. (2009) Intellectual migration in Ukraine in the context of international scientific cooperation. Ukraine: aspects of work. 2009. № 5. S. 34-38.

8. Migration and tolerance in Ukraine / Ed. J. Pylynsky. K .: Stylus. 2007. № 6. 191 p.

9. Semikina M. (2004). Human capital and investment regulation of its mobility in competitive conditions. Bulletin of the Ternopil Academy of National Economy. 2004. Vip. 5-1. Pp. 107-114.

10. Money transfers to Ukraine (2021). Ministry of Finance of Ukraine. URL: https://index.minfin.com.ua/ua/economy/transfer/ (Accessed 13 Jun 2021).

11. European Commission/EACEA/Eurydice (2018). The European Higher Education Area in 2018: Bologna Process Implementation Report. URL: https://eacea.ec.europa.eu/nationalpolicies/eurydice/content/european-higher-education-area-2018-bologna-process-implementation-report_en (Accessed 17 Jun 2021).

12. State Statistics Service of Ukraine (SSSU 2017), Зовнішня Трудова Міграція Населення (за результатами модульного вибіркового обстеження), http://ukrstat.gov.ua/druk/publicat/kat_u/publ11_u.htm(Accessed 15 Jun 2021).

13. Report on the methodology, organization and results of the modular sample survey on labor migration in Ukraine. (2017). Kyiv. URL: http://ukrstat.gov.ua/druk/publicat/kat_u/2013/dop/12_13/zvit.zip (Accessed 15 Jun 2021).

14. Kapur D., McHale J. (2012). Economic Effects of Emigration on Sending Countries, Oxford Handbook of the Politics of International Migration, pp. 131-147 (Accessed 17 Jun 2021).

15. International Organisation for Migration (IOM 2016), Migration as an Enabler of Development in Ukraine. A study on the nexus between development and migration-related financial flows to Ukraine. Kyiv, URL: http://www.iom.org.ua/sites/default/files/iom_migration_as_an_enabler_of_development_in_ukraine.pdf (Accessed 17 Jun 2021).

16. EBRD (2018), Work in Transition, Transition Report 2018-19. URL: https://www.ebrd.com/news/publications/transition-report/transition-report-201819.html (Accessed 15 Jun 2021).

17. COVID-19 crisis puts migration and progress on integration at risk. (2021). URL: https://www.oecd.org/newsroom/covid-19-crisis-puts-migration-and-progress-on-integration-at-risk.htm (Accessed 13 Jun 2021). 